\title{
Deep-water fishing tactics of the Spanish fleet in the Northeast Atlantic. Seasonal and spatial distribution
}

\author{
ANTONIO PUNZÓN ${ }^{1}$, ALBERTO SERRANO ${ }^{1}$, JOSÉ CASTRO ${ }^{2}$, ESTHER ABAD $^{2}$, \\ JUAN GIL $^{3}$ and PILAR PEREDA ${ }^{4}$ \\ ${ }^{1}$ Instituto Español de Oceanografía, PO Box 240, 39004 Santander, Spain. E-mail: antonio.punzon@st.ieo.es \\ ${ }^{2}$ Instituto Español de Oceanografía, Subida a Radio Faro, 50-52, 36390 Vigo, Spain. \\ ${ }^{3}$ Instituto Español de Oceanografía, PO Box 2609, 11006 Cádiz, Spain. \\ ${ }^{4}$ Instituto Español de Oceanografía, Avenida de Brasil, 31, 28020 Madrid, Spain.
}

\begin{abstract}
SUMMARY: The classification and identification of all the Spanish fishing activity targeting deep-sea species was conducted using a non-hierarchical classification technique designed for large matrices (CLARA). Otter trawl and set longlines were the main gears used in deep-sea ecosystems. The otter trawl fleet conducted 3 deep-sea fishing tactics. The only otter trawl fishing tactic targeting deep-sea species was that working in the VI ICES Division and targeting Alepocephalus baiirdi. The other 2 otter trawl fishing tactics targeted shallower shelf demersal resources, deep-sea species being secondary (Phycis blennoides). The longline fleet carried out 7 fishing tactics targeting deep-sea species (Molva spp.; deep water sharks; $P$. blennoides; Pagellus bogaraveo; and Trichiuridae) and 2 fishing tactics targeting Conger conger, which perform as deepsea fishing tactics in the narrow continental shelf area. This classification, together with knowledge regarding their seasonal performance and spatial distribution, may help to design fisheries sampling protocols and to improve the management of these fleets, thus reducing their impact on deep-sea habitats.
\end{abstract}

Keywords: Northeast Atlantic, métiers, fisheries, deep sea, trawl, longline, multivariate.

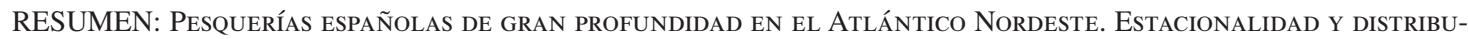
CIÓN ESPACIAL. - Para la clasificación e identificación de todas las pesquerías españolas que actúan sobre especies de gran profundidad se ha utilizado una técnica de cluster no jerárquica diseñada para grandes matrices (CLARA). El arrastre con puertas y el palangre de fondo fueron los aparejos más importantes. Solamente la táctica pesquera de arrastre con puertas desarrollada en la División VI del ICES está dirigida a especies de profundidad, siendo la especie objetivo Alepocephalus baiirdi. Las otras dos tácticas pesqueras con arrastre de puertas son mixtas, teniendo como objetivo especies típicas de plataforma, y teniendo las especies de profundidad como secundarias (Phycis blennoides). La flota de palangre desarrolla siete tácticas pesqueras dirigidas a especies de profundidad: Molva spp.; tiburones de profundidad; P. blennoides; Pagellus bogaraveo; Trichiuridae; y dos pesquerías dirigidas a Conger conger, que se comportan como tácticas pesqueras de profundidad en las zonas de plataforma estrecha. Esta clasificación junto con el conocimiento acerca de su comportamiento estacional y espacial, ayudarán al diseño de los protocolos de muestreo de estas pesquerías así como a la mejora de la gestión de estas pesquerías contribuyendo a una reducción de su impacto en los hábitats profundos.

Palabras claves: Atlántico Nordeste, métiers, pesquerías, mar profundo, arrastre, palangre, multivariante.

\section{INTRODUCTION}

Fisheries operating on deep-sea ecosystems developed mainly after the Second World War (Koslow et al., 2000), owing to the decline in resources on the shelf and in coastal areas. This decline forced fisheries to seek new and unexploited resources and to deveop new techniques for accessing areas beyond the continental shelf (Gordon et al., 2003).

Species living in these deep ecosystems, and hence exploited by deep-sea fisheries, are typically very susceptible to over-exploitation and have slow recovery times (Clark, 2001; Large et al., 2003; Morato et al., 
2006), mainly because of their biological characteristics, i.e. 'K-selected'' life histories characterized by extreme longevity, late maturity ages, slow growth, and low fecundity (Koslow et al., 2000; Lorance and Dupouy, 2001). In general, initial catches or yields obtained from these resources are very high, but are often followed by a severe decline in the production. This is known as the "boom and bust" cycle (Koslow et al., 2000; Clark, 2001). The aforementioned vulnerability of the species, together with the overall exposure and weakness of deep-water habitats, call for urgent action in order to guarantee a sustainable management of the fisheries operating in these ecosystems (Devine et al., 2006).

The main fishing grounds of the non-freezer Spanish fleet are the Celtic Sea and the Southern European Atlantic Shelf (Fig. 1). In the first area the main deep species landings for all UE fleets are composed of Molva spp, Phycis blennoides, Coryphaenoides rupestris and Aphanopus carbo, which have shown a drop in total landings in the last 10 years (ICES, 2010). In the southern area, total landings of deep-water species for all UE fleets remain stable, the main landings being of Aphanopus carbo, Pagellus bogaraveo, Lepidopus caudatus and Molva spp. (ICES, 2010). The main demersal gear used by the Spanish fleet are trawls (otter trawl and pair trawl), gillnets, longlines and pots. Sometimes, as with trawling, it is possible to act on several species at a time, which is defined as a mixed fishery. However, no information concerning the selection or aiming of particular fishing activities towards one or several target species is registered in the relevant fishery statistics, which makes it impossible to define or characterize these fishing tactics (as a combination of gear, target species and working area). This often hinders the identification of a fishing activity aimed specifically at deep-water species, its activity being concealed within others that are not aimed at these ecosystems/species. In the case of mixed fisheries, their activity can only be defined in 2 ways. The most straightforward is a system of licenses which limits the target resource to one. This is the case of the bottom trawl targeting Reinhardtius hippoglossoides in the northeast Atlantic (Iglesias and Paz, 1995). The other, and most common way, is to identify large landings of any deep-sea species. In this case, the activity can only be recognized when it is very substantial, but it is impossible to define the fisheries (by-catch and target species) correctly (Piñeiro et al., 2001; Gordon et al., 2003).

To correctly manage deep-sea ecosystems it is necessary to identify which part of the fishing effort is actually directed to them and in which way it is exerted. Therefore, it is necessary to define and implement a methodology aiming at identifying and monitoring deep-water fishing tactics, as proposed in this paper. Moreover, no research surveys are currently being conducted in the majority of these ecosystems, so information regarding specific effort may also yield good relative abundance indices of the deep-water species that are being targeted by these fisheries (Hilborn and Walters, 1992).
In addition, management of mixed fisheries is complicated under the current advisory system, which mainly focuses on single-stock advice. This system forces management decisions affecting fleets to be driven by the most restrictive stocks. Improving knowledge regarding the nature of these mixed fisheries through tactic classification and characterization may help to identify those fleets, seasons or areas that are not affected by singlestock restrictions. The information presented in this paper will help reconcile the single-stock advice with the mixed nature of the fleet's activity.

\section{MATERIALS AND METHODS}

\section{What do we understand by deep-sea fisheries?}

Traditionally, deep-sea fisheries have been those carried out below the continental shelf $(200 \mathrm{~m})$, but the International Council for the Exploration of the Sea (ICES) considers them to be those undertaken below $400 \mathrm{~m}$. In our case, the fisheries occurring in the study zone target several species and they may be carried out in a wide bathymetric range (from $100 \mathrm{~m}$ to more than $400 \mathrm{~m}$ ). Hence, we have considered deep-sea fisheries as those having some of the species included in regulation (EC) $\mathrm{N}^{\circ} 2270 / 2004$ of the Council, as target or accompanying species, or similar ones. We have also included those having Conger conger as accompanying or target species, since in the study area it occurs below $400 \mathrm{~m}$, and in other areas it is regulated as being a deep-sea species (D'Onghia et al., 2004). Therefore, we have regarded as deep-sea fisheries those having Trichiuridae, Molva spp., deep-water sharks, Conger conger, Phycis blennoides, Beryx spp., Brosme brosme, Pagellus bogaraveo, Hoplostethus spp., Alepocephalidae or Macrouridae.

\section{Data}

We used information from the logbooks of the Spanish non-freezer fleet, working in the northeast Atlantic from 2004 to 2006 (data facilitated by the Spanish Environment Ministry). The information recorded in the logbooks includes landings by boat, trip, fishing day, gear and ICES rectangle $\left(1^{\circ}\right.$ longitude $\mathrm{x} 0.5^{\circ}$ latitude) from the fleet of vessels over $10 \mathrm{~m} \mathrm{LOA}$. From the total demersal fleet required to fill-in the logbooks (1696 boats), we analysed 370345 trips, adding up to 567123 fishing days. We subdivided the original matrix by fishing gear (only demersal ones) and by geographic area. The areas were grouped following the ICES management zones: IXa South (Gulf of Cádiz), IXa NorthVIIIc (Galician Atlantic shelf and Cantabrian Sea) and VIIIab-VII-VI (north of the Bay of Biscay, Gran Sole, Porcupine, Rockall and east of Hatton Bank) (Fig. 1). For the bottom otter trawl matrix, zones VIIIab-VII-VI were considered separately.

The matrix was constructed using catches per trip. This is the sample unit used in the European fisheries 


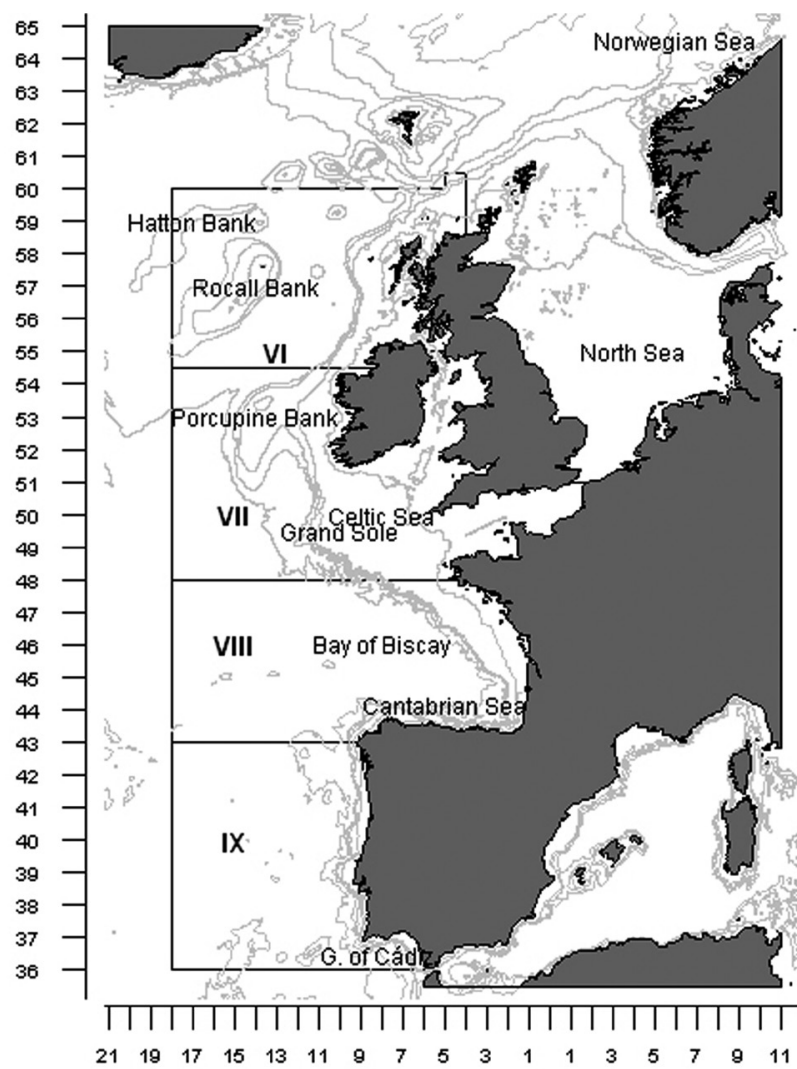

FIG. 1. - Main fishing grounds in the northeast Atlantic for the fleet involved in the study (VI-IX ICES divisions)

sampling programme design for landings and discards, (Commission Decision of $6^{\text {th }}$ of November 2008. 2008/949/EC). The main reason for using the trip is the need to assign each of them to a specific metier or fishing tactic, in order to define and implement the management measures included under the fleet-based approach and the ecosystem approach to fisheries (Vinther et al., 2004; ICES, 2007).

To standardize the landings by trip, the species composition of each trip was expressed as a percentage of the total amount caught in it (Jiménez et al., 2004; Campos et al., 2007). Those species representing less than $1 \%$ of the total landings were incorporated into the matrix in a group called "others". Given the doubtful classification of deep-sea sharks conducted on board, this taxonomic group was separated into 2 categories: deep-sea sharks and "other sharks", which included all remaining sharks, including unidentified species, pelagic species and littoral demersal species.

\section{Identification of the fisheries}

For this identification we used ordination and classification techniques. The ordination technique was used to evaluate associations among variables (species) that characterized cases (trips) (Gordon, 1999), and to help to interpret the final result obtained with the classification technique. We also used it in those cases in which the association was weak (Struyf et al., 1996).
To choose the most appropriate ordination technique between correspondence analysis and principal component analysis (PCA), we conducted a detrended correspondence analysis (DCA) (Hill and Gauch, 1980).

With the classification technique we assigned each trip to a fishing tactic. We used the CLARA (Clustering Large Applications) non-hierarchical clustering technique, which is especially designed for big matrices (Kaufman and Rousseeuw, 1986). This technique is based on the $\mathrm{k}$-medoid partition method (partition around medoids). We used the Euclidean distance as dissimilarity coefficient. The sample size was $40+2 * \mathrm{k}$, where $\mathrm{k}$ was the number of clusters. The number of iterations for each matrix was 5 . To choose the number of conglomerates we used the silhouette width (Rousseeuw, 1987), and to determine whether the resulting structure was good or not we followed the criteria of Struyf et al. (1996), in which 4 levels are defined for the silhouette's global coefficient (SGC): 0.711 , consistent pattern; 0.51-0.70, reasonable pattern; $0.26-0.50$, weak pattern; $<0.26$, no pattern. Moreover, for each of the identified groups a partial coefficient silhouette (PCS) was obtained, indicating the internal homogeneity of the cluster and how heterogeneous it was with respect to those nearest to it, using the same levels as those defined for the SGC.

The analyses were performed on $\mathrm{R}$ ( $\mathrm{R}$ Development Core Team, 2005), the DCA with the "vegan" library (Oksanen et al., 2006), the correspondence and principal component analyses with the "ade4" library (Chessel et al., 2005) and the cluster analyses with the "cluster" (Maechler et al., 2005) and "stats" (R Development Core Team, 2005) libraries.

The codification used for the various fishing tactics was based on the international code for gear type (FPO, Pots and Traps; GNS, Set Gillnet; LHM, Hand Lines; LLS, Set longlines; OTB, Bottom Otter Trawl; PTB, Bottom Pair Trawl), fishing area (ICES zone code: IXa South, IXa North, VIIIc, VIIIab, VII, VI) and target species, respectively.

\section{Characterization of the fisheries}

To characterize each fishing tactic, the percentage in weight and the frequency of occurrence were used. We also used the feeding index (Lauzanne, 1975) to analyse the effects of percentage in weight and frequency of occurrence combined. This index may vary between 0 and 100 (Rosecchi and Nouaze, 1985). Since many fisheries were analysed, to avoid excessively long tables only the 5 most important species according to the feeding index are shown.

Fishing day was used as the effort unit. To investigate seasonal patterns we calculated the percentage of fishing days per month. For the spatial distribution of effort we used the number of fishing days per ICES statistical rectangle during the 3 years of study. In the latter case all information that was not geo-referenced was eliminated. 
TABLE 1. - Relative importance of deep-sea fisheries compared to all other fisheries (per gear and zone) (SGC, silhouette global coefficient; Norm. No deep water fishing tactic; Dmix, demersal and deep-water fishing tactic mix; Deep, deep-water fishing tactic).

\begin{tabular}{|c|c|c|c|c|c|c|c|c|c|c|c|c|c|c|}
\hline Gear & ICES Area & SGC & \multicolumn{3}{|c|}{ Fishing tactics } & $\begin{array}{l}\text { Vesse } \\
\text { Norm }\end{array}$ & $\begin{array}{l}\text { ls by } 1 \\
\text { Dmix }\end{array}$ & $\begin{array}{r}\text { nonth } \\
\text { Deep }\end{array}$ & Norm & $\begin{array}{l}\text { Trips } \\
\text { Dmix }\end{array}$ & Deep & \multicolumn{3}{|c|}{$\begin{array}{l}\text { Fishing days } \\
\text { Norm Dmix Deep }\end{array}$} \\
\hline Otter trawl (OTB) & VI & 0.49 & 50 & 0 & 50 & 54 & 0 & 46 & 72 & 0 & 28 & 45 & 0 & 55 \\
\hline Otter trawl (OTB) & VII & 0.31 & 67 & 33 & 0 & 70 & 30 & 0 & 82 & 18 & 0 & 83 & 17 & 0 \\
\hline Otter trawl (OTB) & VIIIabde & 0.27 & 80 & 20 & 0 & 61 & 39 & 0 & 96 & 4 & 0 & 98 & 2 & 0 \\
\hline Otter trawl (OTB) & VIIIc+IXa North & 0.52 & 100 & 0 & 0 & 100 & 0 & 0 & 100 & 0 & 0 & 100 & 0 & 0 \\
\hline Otter trawl (OTB) & IXa South & 0.28 & 100 & 0 & 0 & 100 & 0 & 0 & 100 & 0 & 0 & 100 & 0 & 0 \\
\hline Pair trawl (PTB) & VI-VII-VIIIabde & 0.67 & 50 & 50 & 0 & 68 & 32 & 0 & 77 & 23 & 0 & 79 & 21 & 0 \\
\hline Pair trawl (PTB) & VIIIc+IXa North & 0.78 & 100 & 0 & 0 & 100 & 0 & 0 & 100 & 0 & 0 & 100 & 0 & 0 \\
\hline Hooks (LLS and LHM) & VI-VII-VIIIabde & 0.63 & 20 & 0 & 80 & 85 & 0 & 15 & 60 & 0 & 40 & 66 & 0 & 34 \\
\hline Hooks (LLS and LHM) & VIIIc+IXa North & 0.6 & 57 & 14 & 29 & 25 & 42 & 33 & 47 & 16 & 37 & 45 & 20 & 35 \\
\hline Hooks (LLS and LHM) & IXa South & 0.86 & 33 & 0 & 67 & 33 & 0 & 67 & 8 & 0 & 92 & 9 & 0 & 91 \\
\hline Gillnet (GNS) & VI-VII-VIIIabde & 0.61 & 67 & 0 & 33 & 54 & 0 & 46 & 73 & 0 & 27 & 73 & 0 & 27 \\
\hline Gillnet (GNS) & VIIIc+IXa North & 0.48 & 100 & 0 & 0 & 100 & 0 & 0 & 100 & 0 & 0 & 100 & 0 & 0 \\
\hline Gillnet (GNS) & IXa South & 0.57 & 100 & 0 & 0 & 100 & 0 & 0 & 100 & 0 & 0 & 100 & 0 & 0 \\
\hline Traps (FPO) & VIIIc+IXa North & 0.86 & 100 & 0 & 0 & 100 & 0 & 0 & 100 & 0 & 0 & 100 & 0 & 0 \\
\hline Traps (FPO) & IXa South & 0.9 & 100 & 0 & 0 & 100 & 0 & 0 & 100 & 0 & 0 & 100 & 0 & 0 \\
\hline
\end{tabular}

TABLE 2. - Catch profile (percentage in weight, frequency of occurrence and feeding index) by cluster and area for bottom otter trawl (OTB) (PCS: partial coefficient silhouette).

\begin{tabular}{lllccc}
\hline ICES Area & Cluster Names (PCS) & Species & Landings (\%) & FO & FI \\
\hline VI & OTB_VI_Alepocephalus (0.59) & Alepocephalus bairdii & 53.2 & 100.0 & 53.2 \\
& & Macrouridae & 39.7 & 85.5 & 33.9 \\
& & Actinopterygii & 1.7 & 78.2 & 1.3 \\
& & Others & 1.2 & 84.5 & 1.0 \\
VII & Elasmobranchii & 1.2 & 74.5 & 0.9 \\
& OTB_VII_Mix demersal (0.56) & Merluccius merluccius & 52.1 & 99.6 & 51.9 \\
& & Lophius spp. & 21.3 & 91.9 & 19.5 \\
VIIIabde & Nephrops norvegicus & 7.9 & 90.2 & 7.1 \\
& & Phycis blennoides & 7.0 & 77.5 & 5.4 \\
& & Lepidorhombus spp. & 2.8 & 88.3 & 2.4 \\
& & Merluccius merluccius & 79.2 & 100.0 & 79.2 \\
& & Lophius spp. & 11.4 & 84.0 & 9.5 \\
& & Phycis blennoides & 5.9 & 36.0 & 2.1 \\
\end{tabular}

TABLE 3. - Catch profile (percentage in weight, frequency of occurrence and feeding index) by cluster and area for pair bottom trawl (PTB) and gillnet (GNS) (PCS: partial coefficient silhouette).

\begin{tabular}{|c|c|c|c|c|c|}
\hline ICES Area & Cluster Names (PCS) & Species & Landings $(\%)$ & $\mathrm{FO}$ & FI \\
\hline \multirow[t]{8}{*}{ VI-VII-VIIIabde } & PTB_VI-VII-VIIIab_Mix demersal (0.12) & Merluccius merluccius & 18.1 & 93.9 & 17.0 \\
\hline & & Others & 16.7 & 85.1 & 14.2 \\
\hline & & Trachurus spp. & 15.3 & 39.4 & 6.0 \\
\hline & & Ommastrephidae & 12.6 & 38.8 & 4.9 \\
\hline & & Trisopterus spp. & 8.1 & 51.6 & 4.2 \\
\hline & & Merlangius merlangus & 7.8 & 30.8 & 2.4 \\
\hline & & Actinopterygii & 2.8 & 72.2 & 2.0 \\
\hline & & Phycis blennoides & 7.7 & 23.1 & 1.8 \\
\hline \multirow[t]{5}{*}{ VI-VII-VIIIabde } & GNS_VI-VII-VIIIab_Mix demersal (0.22) & Molva spp. & 22.2 & 56.3 & 12.5 \\
\hline & & Beryx spp. & 20.9 & 42.1 & 8.8 \\
\hline & & Merluccius merluccius & 13.2 & 66.4 & 8.8 \\
\hline & & Others & 7.1 & 71.8 & 5.1 \\
\hline & & Phycis blennoides & 12.6 & 32.0 & 4.0 \\
\hline
\end{tabular}

\section{RESULTS}

Two types of deep-water fishing tactics were defined: deep water fisheries sensu stricto (fisheries targeting deep-water species) and mixed deep-sea fisheries, in which deep-sea species were accompanying species and the target ones were those with a shallower affinity. Of the 53 fishing tactics identified, 10 targeted deep-sea species, and 4 were mixed deep-sea fisheries. Table 1 shows the global silhouette coefficients for each matrix and the relative importance of fishing tactics targeting deep-sea species per fishing gear and zone. All fishing tactics, except otter trawl in VII, VIIIabde and IXA South zones, had a consistent structure, their global silhouette coefficient always being higher than 0.48 .

Of all the fishing tactics identified (Tables 2-5), 4 were deep fishing tactics with partial silhouette coefficients (PCS) lower than 0.25 (Table 3-5), and hence did not have a sufficiently defined identity to be con- 
TABLE 4. - Catch profile (percentage in weight, frequency of occurrence and feeding index) by cluster and area for longline in VI, VII and VIIIab ICES divisions (PCS: partial coefficient silhouette).

\begin{tabular}{|c|c|c|c|c|c|}
\hline ICES Area & Cluster Names (PCS) & Species & Landings $(\%)$ & $\mathrm{FO}$ & FI \\
\hline VI-VII-VIIIabde & $\begin{array}{l}\text { LLS_VI-VII-VIIIab_Phycis (0.11) } \\
\text { LLS_VI-VII-VIIIab_Deep Sharks (0.89) }\end{array}$ & $\begin{array}{l}\text { Conger conger } \\
\text { Molva spp. } \\
\text { Others } \\
\text { Merluccius merluccius } \\
\text { Helicolenus dactylopterus } \\
\text { Molva spp. } \\
\text { Merluccius merluccius } \\
\text { Helicolenus dactylopterus } \\
\text { Phycis blennoides } \\
\text { Others } \\
\text { Phycis blennoides } \\
\text { Others } \\
\text { Merluccius merluccius } \\
\text { Conger conger } \\
\text { Molva spp. } \\
\text { Deep-water Elasmobranchii } \\
\text { Phycis blennoides } \\
\text { Others } \\
\text { Molva } \text { spp. } \\
\text { Conger conger }\end{array}$ & $\begin{array}{l}68.4 \\
14.4 \\
13.2 \\
1.8 \\
1.1 \\
68.9 \\
10.9 \\
4.2 \\
3.4 \\
3.5 \\
24.4 \\
16.3 \\
12.0 \\
8.4 \\
11.1 \\
88.0 \\
4.3 \\
6.0 \\
0.6 \\
0.2\end{array}$ & $\begin{array}{l}100.0 \\
83.4 \\
87.5 \\
28.0 \\
11.5 \\
100.0 \\
71.3 \\
59.6 \\
54.3 \\
50.9 \\
62.2 \\
69.7 \\
54.8 \\
72.4 \\
50.8 \\
100.0 \\
83.5 \\
54.5 \\
3.3 \\
6.6\end{array}$ & $\begin{array}{l}68.4 \\
12.0 \\
11.6 \\
0.5 \\
0.1 \\
68.9 \\
7.8 \\
2.5 \\
1.8 \\
1.8 \\
15.2 \\
11.4 \\
6.6 \\
6.1 \\
5.7 \\
88.0 \\
3.6 \\
3.3 \\
0.0 \\
0.0\end{array}$ \\
\hline
\end{tabular}

sidered specific fishing tactics as such. An example can be seen in Figure 2, where the PCA for longline trips in zones VI-VII-VIIIabde shows how all samples (trips) belong to fishing tactics with PCS higher than 0.5 (all targeting M. merluccius, Molva spp., Conger conger and deep-water sharks), indicating a high affinity (Table 4). On the other hand, those trips targeting $P$. blennoides $(\mathrm{PCS}=0.11)$ overlapped with all other samples and showed a low affinity among them (Fig. 2). Moreover, the catch profile of the 4 fishing tactics with PCS below 0.25 did not include any species common to all trips and none of them reached the target species level according to the feeding index. Hence, the clusters with low PCS were rejected as fishing tactics.

\section{Bottom otter trawl}

Three bottom otter trawl deep-water fisheries were identified. Two mixed fisheries targeting $M$. merluccius were carried out in zones VII (OTB_VII_Mix demersal) and VIIIabde (OTB_VIIIab_Mix demersal) (Table 2), and had P. blennoides as a deep-water accompanying species. The other fishery was in zone VI targeting $A$. bairdii (OTB_VI_Alepocephalus) (Table 2).

In the OTB_VIIIab_Mix demersal fishery P. blennoides was the third most important species being landed $(5.9 \%)$, despite appearing only in $36 \%$ of the trips (Table 2). According to the feeding index, its importance was secondary (FI=2.1). In the OTB_VII_Mix demersal fishery, $P$. blennoides was the fourth species in weight (7\%), and was represented in $77.5 \%$ of the trips $(\mathrm{FI}=5.4)$.

In the OTB_VI_Alepocephalus fishing tactic the species A. bairdii represented $53 \%$ of the total landings in weight, was caught on all trips, and was dominant according to the FI (Table 2). The second species in weight were those belonging to the family Macrouridae $(39.7 \%)$, which were captured on $85 \%$ of the trips, and

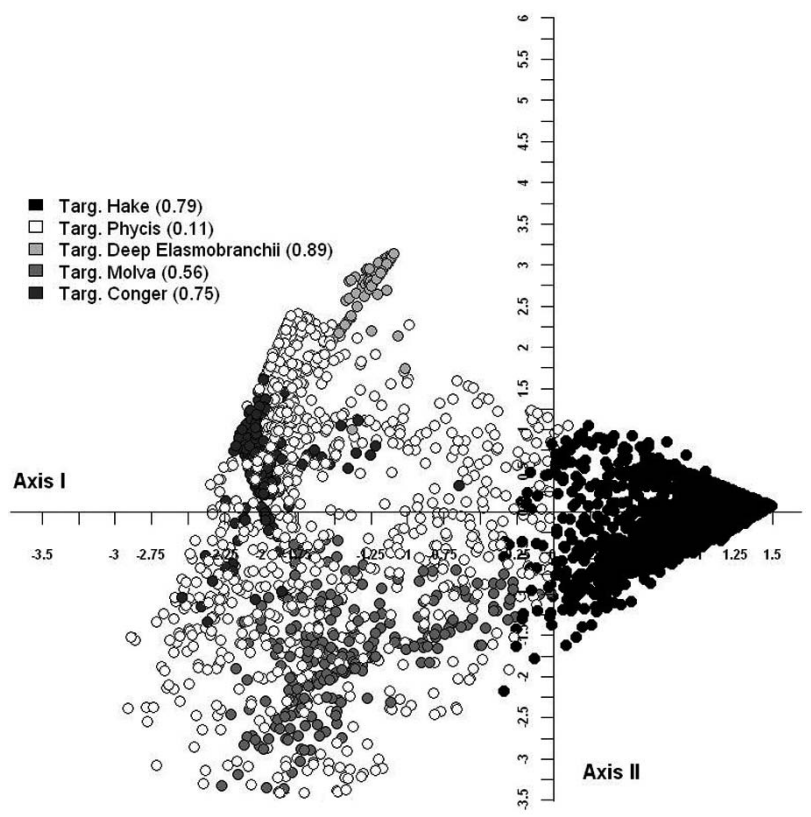

FIG. 2. - Correspondence analysis for the Bay of Biscay longline trips identified according to the cluster or fishing tactic to which they were assigned.

can be considered essential $(\mathrm{FI}=33.9)$. The presence of $P$. blennoides and species of the family Trichiuridae (62.7\% and $60 \%$ of the trips, respectively) should be highlighted, even if their importance in weight was low (they are not shown in the table because they are not among the 5 most important). About $50 \%$ of the vessels and of the days spent there were devoted to exploiting these resources (Table 1).

Taking into account that in the case of the fishing tactic targeting A. bairdii in ICES Area VI only $0.2 \%$ of the fishing days have associated spatial information (ICES rectangle), the highest effort values were obtained on the Porcupine Bank and south of it (Fig. 


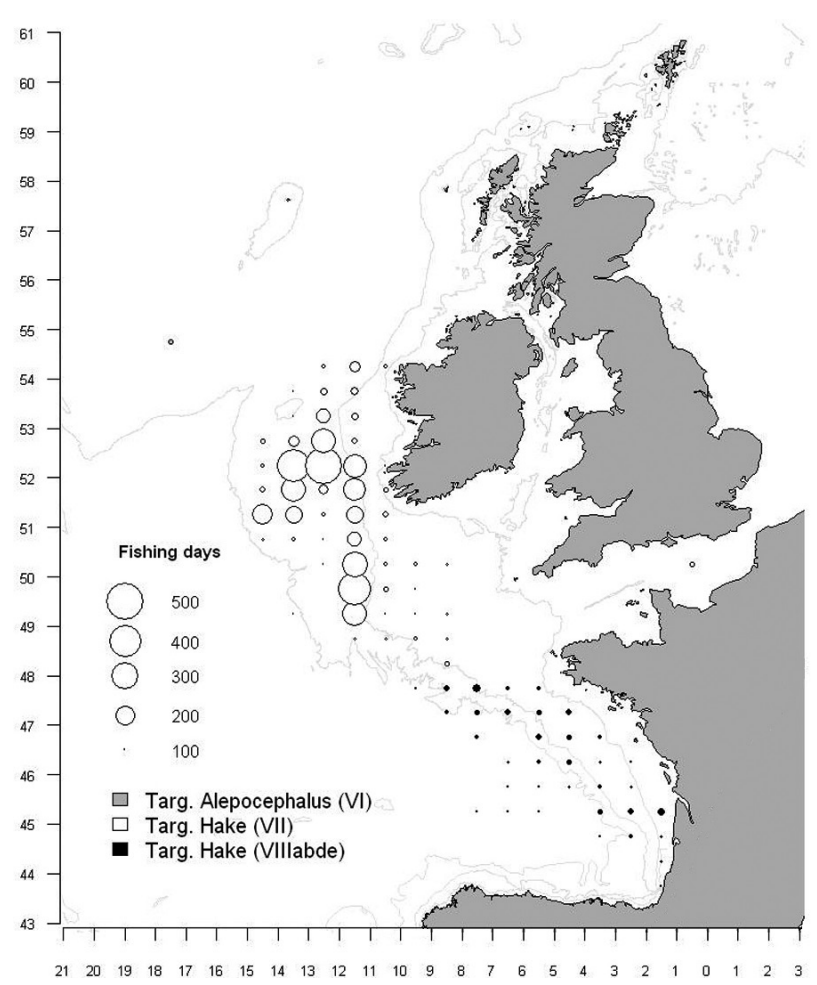

FIG. 3. - Spatial distribution of effort (fishing days) by deep fishing tactic from otter trawl in ICES Divisions VI, VII and VIIIabde

3). The spatial distribution of effort in zone VIIIabde was homogeneous throughout the French shelf. With regards to the OTB_VI_Alepocephalus fishery, the majority of the activity was carried out in zone VIb of ICES (93\% of the fishing days), although the information per statistical rectangle was poor.

Only the OTB_VIIIab_Mix demersal fishery showed a marked seasonality, more than $50 \%$ of the fishing days being in November and December (Fig. 4). As regards the OTB_VI_Alepocephalus fishery, the effort was homogeneous throughout the year, except for January, when an important decrease was observed. Significantly more fishing days occurred from the end of spring and throughout the summer in the OTB_VII_ Mix demersal fishery.

\section{Hooks}

In this type, 7 deep-sea fishing tactics with a PCS close to or higher than 0.5 were identified (Tables 1-5). Three different fishing tactics were carried out in the VI-VII-VIIIabde (targeting Molva spp., C. conger and deep sharks), 2 in the VIIIc and IXa North ICES divisions (targeting $C$. conger and $P$. blennoides) and 2 in the Gulf of Cádiz (targeting $P$. bogaraveo and Trichiuridae).

In the VI-VII-VIIIabde zones, an average of $15 \%$ of the vessels per month exploited these resources, using $34 \%$ of the fishing days (Table 1). The fishery targeting Molva spp. landed these species on all trips and represented $70 \%$ of the landings (Table 4). The second species in terms of catches was $M$. merluccius, which was landed on $71 \%$ of the trips and can be considered secondary $(\mathrm{FI}<10)$.

TABLE 5. - Catch profile (percentage in weight, frequency of occurrence and feeding index) by cluster and area for longline in VIIIc, IXa North and IXa South ICES Divisions (PCS: partial coefficient silhouette).

\begin{tabular}{|c|c|c|c|c|c|}
\hline ICES Area & Cluster Names (PCS) & Species & Landing $(\%)$ & $\mathrm{FO}$ & FI \\
\hline VIIIc and & \multirow[t]{5}{*}{ LLS_VIIIc and IXa N_Conger (0.87) } & Conger conger & 93.0 & 100.0 & 93.0 \\
\hline \multirow[t]{18}{*}{ IXa North } & & Others & 2.3 & 25.4 & 0.6 \\
\hline & & Actinopterygii & 1.7 & 24.3 & 0.4 \\
\hline & & Phycis blennoides & 2.6 & 10.6 & 0.3 \\
\hline & & Pollachius spp. & 0.1 & 1.5 & 0.0 \\
\hline & \multirow[t]{5}{*}{ LLS_VIIIc and IXa N_Phycis (0.74) } & Phycis blennoides & 70.2 & 100.0 & 70.2 \\
\hline & & Conger conger & 12.2 & 37.2 & 4.5 \\
\hline & & Actinopterygii & 7.5 & 45.6 & 3.4 \\
\hline & & Others & 4.4 & 25.2 & 1.1 \\
\hline & & Deep-water Elasmobranchii & 2.4 & 7.3 & 0.2 \\
\hline & \multirow[t]{9}{*}{ LLS_VIIIc and IXa N_Brama (0.07) } & Brama brama & 45.6 & 15.5 & 7.1 \\
\hline & & Merluccius merluccius & 4.6 & 35.8 & 1.7 \\
\hline & & Pagellus bogaraveo & 3.6 & 40.5 & 1.5 \\
\hline & & Micromesistius poutassou & 2.5 & 33.9 & 0.9 \\
\hline & & Beryx spp. & 3.1 & 27.7 & 0.8 \\
\hline & & Actinopterygii & 3.6 & 21.0 & 0.8 \\
\hline & & Others & 1.8 & 34.8 & 0.6 \\
\hline & & Elasmobranchii & 7.5 & 6.4 & 0.5 \\
\hline & & Deep-water Elasmobranchii & 12.5 & 3.4 & 0.4 \\
\hline \multirow[t]{10}{*}{ IXa South } & \multirow[t]{5}{*}{ LHM_IXa S_Pagellus (0..87) } & Pagellus bogaraveo & 92.1 & 100.0 & 92.1 \\
\hline & & Others & 4.5 & 16.2 & 0.7 \\
\hline & & Trichiuridae & 1.7 & 5.9 & 0.1 \\
\hline & & Sparidae & 1.5 & 4.6 & 0.1 \\
\hline & & Elasmobranchii & 0.1 & 0.8 & 0.0 \\
\hline & \multirow[t]{5}{*}{ LLS_IXa S_Trichiuridae (0.93) } & Trichiuridae & 99.1 & 100.0 & 99.1 \\
\hline & & Pagellus bogaraveo & 0.5 & 3.8 & 0.0 \\
\hline & & Others & 0.3 & 3.8 & 0.0 \\
\hline & & Sparidae & 0.0 & 0.8 & 0.0 \\
\hline & & Deep-water Elasmobranchii & 0.0 & 0.5 & 0.0 \\
\hline
\end{tabular}



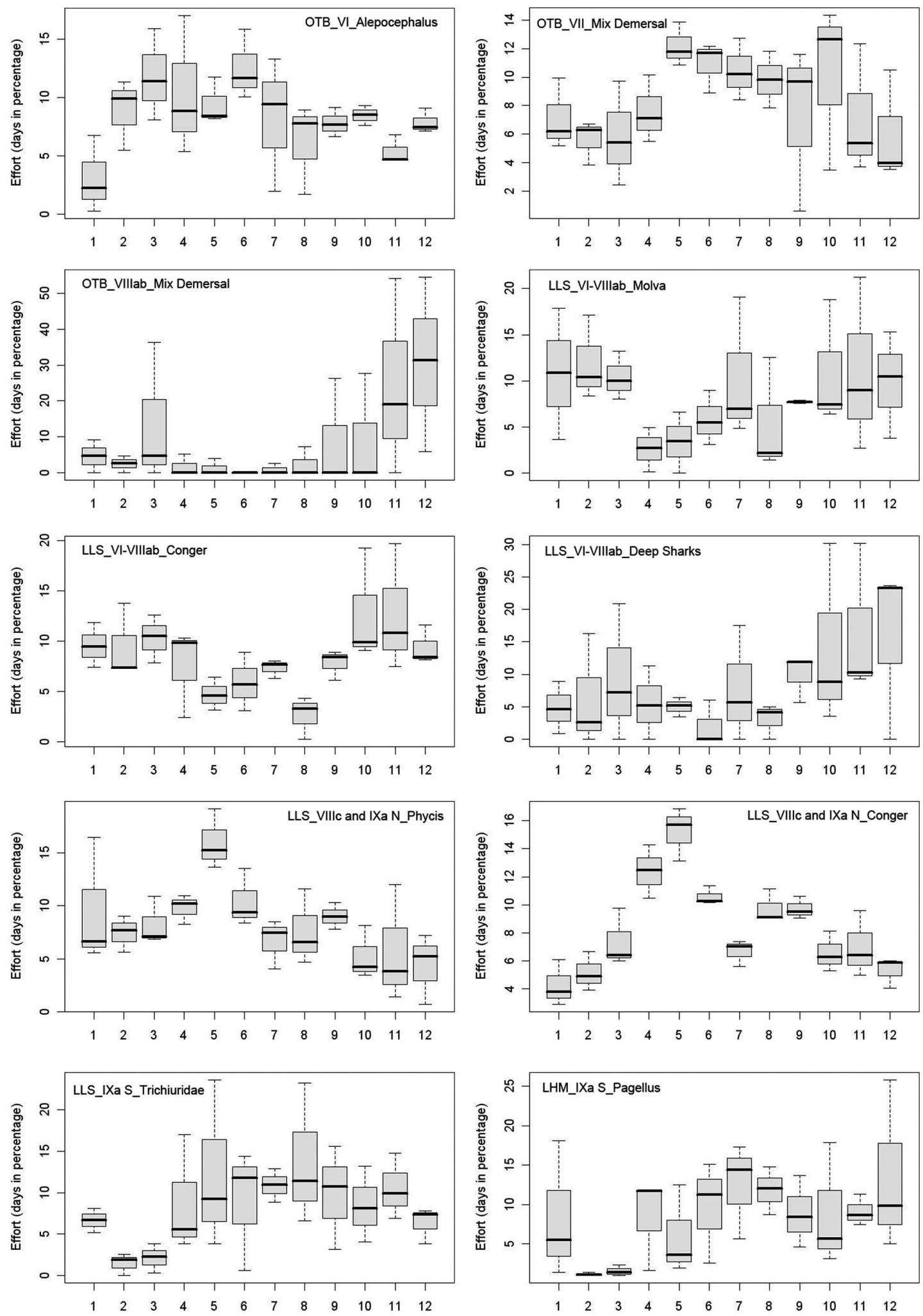

FIG. 4. - Seasonality of the effort by fishing tactics (by row and from top to bottom): Otter trawl targeting Alepocephalus baiirdi in VI ICES Division. Otter trawl targeting M. merluccius in VII. Otter trawl targeting M. merluccius in VIIIabde. Longlines targeting Molva in VI. VII and VIIIabde. Longlines targeting Conger conger in VI, VII and VIIIabde. Longlines targeting deep sharks in VI, VII and VIIIabde. Longlines targeting Phycis blennoides in VIIIc and IXa North. Longlines targeting Conger conger in VIIIc and IXa North. Longlines targeting Trichiuridae in IXa South and handlines targeting Pagellus bogaraveo in IXa South. 

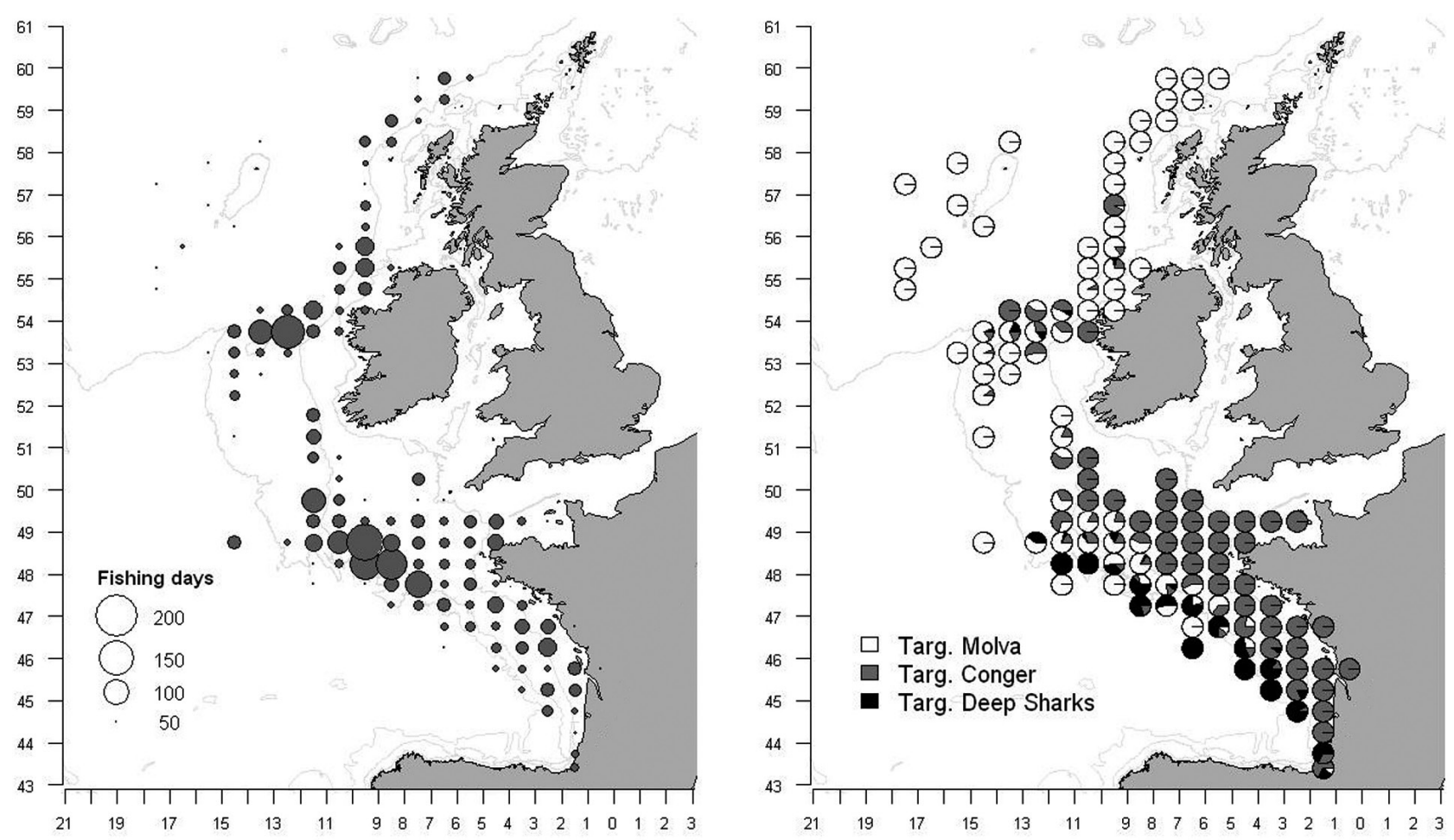

FIG. 5. - Spatial distribution of effort (left) and relative importance by fishing tactic and ICES rectangle of longline in ICES Divisions VI, VII and VIIIabde (right).

Conger conger was landed on all trips of the fishing tactic LLS_VI-VII-VIIIab_Conger, and represented $68 \%$ of its landings (Table 4). LLS_VI-VII-VIIIab_ Conger has 2 accompanying species, Molva spp. and the group of "others" (14.4\% and $13.2 \%$ of the landings, respectively) both of which were caught on more than $80 \%$ of the trips. Both species/groups can be considered relatively important $(10<\mathrm{FI}<25)$. As regards the fishery targeting deep-water sharks, $88 \%$ of the landings belonged to these elasmobranchs, which were also landed on all trips (Table 4). The second species in weight was P. blennoides (4.3\%), which was landed on $83 \%$ of the trips.

The areas with a higher hook fishing effort were the Porcupine and the Grand Sole Banks (Fig. 5). The LLS VI_VIIIab_Conger fishery was carried out mainly on the French shelf, while the LLS_VI-VII-VIIIab_Molva one was conducted mainly in Grand Sole and Porcupine. Fishing tactic LLS_VI-VII-VIIIab_Deep Sharks was only carried out on the continental slope of the French shelf. For fisheries LLS_VI-VII-VIIIab_Molva and LLS_VI-VII-VIIIab_Conger, a significantly lower effort was exerted during the summer (Fig. 4). As regards the fishery targeting deep-sea sharks, the highest effort levels were reached during the last 4 months of the year.

In divisions VIIIc and IXa North, 33\% of the vessels carried out deep water fisheries, investing $35 \%$ of the fishing days (Table 5). The LLS_VIIIc-IXaN_Conger was almost monospecific, 93\% of the landings belonging to the target species. In the LLS_VIIIc-IXaN_Phycis fishery, $70 \%$ of the landings belonged to this spe- cies. The second species in importance was $C$. conger, with $12.2 \%$ of the landings, though it was landed on only $37 \%$ of the trips $(\mathrm{FI}<10)$. The highest effort zone was the central Cantabrian Sea, and to a lesser extent, the western zone (Fig. 6). The fishing tactic targeting C. conger was the most important one in the areas with higher efforts, as was the case in all remaining statistical rectangles close to the coast (Fig. 6). As regards the external statistical rectangles, in the majority of cases, apart from the western zone, the most important fishery was that targeting P. blennoides. The seasonal trend was very similar for both fisheries, the effort being significantly higher between late spring and early summer than during the rest of the year (Fig. 4).

Sporadic landings of deep-sea sharks from the Cantabrian Sea (Division VIIIc of ICES) were detected through the Information and Sampling Network that the IEO (Spanish Institute of Oceanography) has in all Atlantic landing harbours. These trips were not identified by our classification, although the proportion of sharks caught on them was $12 \%$ in the LLS_VIIIcIXaN_Brama fishing tactic (Table 5). To identify whether these low-affinity trips had an internal structure, we classified the trips appearing in this group. The optimal number of clusters obtained was 7 , with a global silhouette coefficient of 0.51 , indicating that the classification was acceptable. Of these 7 clusters, 4 had a partial coefficient above 0.5 . One of them targeted deep-water sharks and $95.3 \%$ of the landings belonged to this faunal group. This cluster had a silhouette coefficient of 1.0. Another of the resulting clusters had 

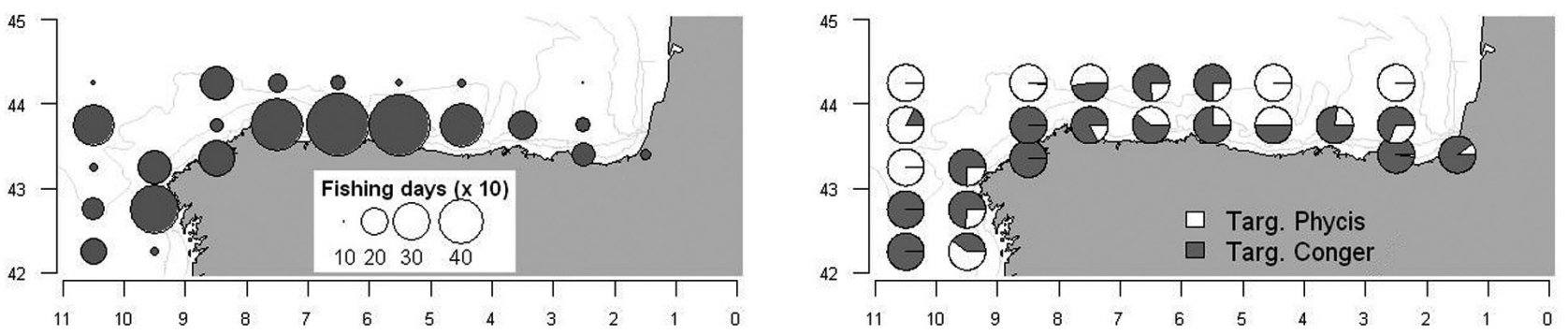

FIG. 6. - Spatial distribution of effort (left) and relative importance by fishing tactic and ICES rectangle from longline in ICES Divisions IXa North and VIIIc (right).

Pagellus bogaraveo (red seabream) as the main species and a partial silhouette coefficient of 0.4 , meaning that its structure was not as consistent as that of the former group. This species was landed on all trips assigned to this cluster and accounted for $62 \%$ of the landings.

In the Gulf of Cádiz $67 \%$ of the hook fleet carried out deep-water fishing tactics, $92 \%$ of the fishing days being devoted to these tactics (Table 1). Two fishing tactics were identified: handline targeting $P$. bogaraveo and set long line targeting Trichiuridae (according to Gil, 2006. the species captured was Lepidopus caudatus) (Table 5). Neither fishery had accompanying species, and $90 \%$ of the landings belonged to the targeted species. Also, the seasonal pattern for both tactics was very similar, efforts being significantly lower in February and March (Fig. 4). In this area, 57\% of the fishing days recorded in the logbook belonged to the fishing tactic targeting Trichiuridae. Since the study area is relatively small, the information provided per statistical rectangle was poor, but according to Gil (2006), these fisheries are conducted in the Gibraltar Straight, between 350 and $700 \mathrm{~m}$ depth.

\section{DISCUSSION}

Deep-water fisheries have usually been studied using only descriptive statistics (Piñeiro et al., 2001; Gordon et al., 2003). Here, by using the classification technique CLARA (Castro et al., 2010, Punzón et al., 2010), we have been able to conduct a quick global study of the fishing activity undertaken by the Spanish fleet in areas VI-IX of the ICES. This technique identifies and classifies the fishing activity associated with deep-water ecosystems objectively, and as a function of the composition of landings per trip, without having to perform surveys/enquiries or identifications per landed volume.

A characteristic of this technique is that it is not as sensitive to atypical elements as hierarchical techniques or those based on the centroid method (Hair et al., 1999; Milligan, 1980). This is an advantage when one is working with matrices built with samples showing a high variability and uncertainty, such as those coming from fishing activities. On the other hand, it can be a handicap in those cases in which certain activities are not well represented. This is the case of the longline fishery targeting deep-water sharks in the Cantabrian
Sea. Hence, previous knowledge on the particularities of a specific fishery can help to detect these situations or to systematically apply classification techniques to these poorly identified groups.

According to background information of the study area (Piñeiro et al., 2001; Gordon et al., 2003) and that obtained from fish market samplers, the only fishery which was not detected in our study was the trap net targeting king crab (Chaceon affinis). This fishery can be considered extinct, since it was only performed by a single vessel in 1996. It should also be taken into account that vessels carrying out this fishery were small (Piñeiro et al., 2001). The participation of vessels smaller than $15 \mathrm{~m}$ in deep-water fisheries makes it impossible to detect their activity, since they are not forced to fill in log books. This situation is even worse on narrow continental shelves such as those surrounding the Iberian Peninsula, since the slope area can easily be reached by vessels with limited navigation capacities.

Situations such as that described above, in which small boats work on narrow shelves, can cause an increase in the importance of deep-sea fisheries because of the decline in coastal or traditionally exploited populations (Clark, 2001; Haedrich et al., 2001). This process could be accentuated by proximity to the traditional fishing grounds and by the wide range of vessels participating in them, from small scale fleets to industrial ones, and a high percentage of this activity is not detected through official information.

With the available data, we can only conclude that bottom otter trawl and hook were the sole gears acting on deep-sea ecosystems. As regards trawling, 2 of the 3 fisheries involved were of the mixed type. In both cases the target species was $M$. merluccius and the main deep-sea accompanying species $P$. blennoides (ICES, 2008), which was more important in catches from the northern area (zone VII of ICES), where most fishing effort was deployed (divisions VIIcjk). In disagreement with what was reported in ICES (2008), we did not detect mixed-trawl fisheries targeting $M$. merluccius in area VI of ICES with any relevant deepsea accompanying species. This may be because ICES (2008) did not take into account the existence of different fishing tactics and the logbooks were not used for spatial segregation of fishing activity, so fishing tactics and areas may be mixed. 
The high effort observed in area VII (OTB_VII_Mix demersal) could be due to the fact that a favourable climatology facilitates working in this fishing ground, and that this season is when the highest Norway lobster yields are obtained (Herráiz et al., 2009). This crustacean is one of the main by-catch species (in economic value) of this fishery. In zone VIIIabde, though the effort exerted on deep-sea fisheries was low, the high values obtained could respond to the fact that in winter the fleet works in areas where climate is more favourable.

The only trawl fishery targeting deep-sea species was conducted in zone VI. Although information per statistical rectangle was poor, this fishery could be the bottom otter trawl fishery operating in the Hatton Bank area, in ICES zones VIb1 and XIIb, which was described by Durán and Román (2001) and ICES (2008). In disagreement with Durán and Román (2001), in our study more than half of the landings were of Alepocephalus bairdii, the second group in importance being Macrouridae (Coryphaenoides rupestris). These differences could be explained by the fact that our information is from area VI, while Durán and Román (2001) used data from areas VI-XIIb, which would also explain the differences found in the specific composition of the remaining accompanying species. The decline in fishing days observed in January was due to a reduction in the fleet's activity in the area, since it was working in other zones (Durán and Román, 2001).

Piñeiro et al. (2001) identified longline mixed fisheries which had P. blennoides, Molva spp., and Pagellus bogaraveo as the main accompanying species. In our study, 2 fisheries were identified as targeting the first 2 species. The first one, having P. blennoides as the target species in Division VIIIc and as the main accompanying species of the fishery targeting deep-water sharks in Division VIIIabde. The other one had Molva spp. as the target species and was carried out in zones VII and VIIIabde of ICES. It is possible that Piñeiro et al. (2001) did not identify their existence or importance because they were working with total catch instead of with the specific composition of the catch per trip. As for $P$. bogaraveo, before the 1990s there was an important fishery targeting this species in Division VIIIc, but the severe decline of the population in the area led to the near-disappearance of this activity (Gil, 2006).

However, we detected a $P$. bogaraveo fishery by analysing a cluster internally (with a low silhouette coefficient). Punzón and Gancedo (1998) also identified this fishery by the frequency of its occurrence on trips of the artisanal fleet using bottom-set longline. The fact that it can be identified by the species presence but not by the amounts obtained can be explained by its high economic value, which compensates for the low yields. This fishery was not identified in our first analysis of the cluster since it was mainly conducted by the artisanal fleet of Division VIIIc of ICES, and hence had a low presence in the logbooks. Something similar hap- pened with the fishery targeting deep-sea sharks, which was detected by Punzón and Gancedo (1998) and by Piñeiro et al. (2001) in Division VIIIc, and was only identified in the present study when the internal structure of 1 of the clusters was investigated. The technique is thus limited by the use of catch in weight, the correct definition of the target species being a combination of weight and economic value, information which was not available for this paper (Punzón et al. 2010).

The fishery targeting $C$. conger on the northern part of the French shelf is a typical shelf fishery, which is mainly conducted at shallower depths than those of Molva spp. Conversely, in the southern area, where the shelf is narrower, the fishery is conducted closer to the slope area. This situation is similar to that found in the Cantabrian Sea with fisheries targeting $P$. blennoides and $C$. conger. Though the small size of the statistical rectangles does not allow precise identification of working areas, on narrow shelves and with species with a wide bathymetric range, such as $C$. conger (Froese and Pauly, 2007) or P. blennoides, an overlap of niches may occur (Sánchez and Serrano, 2003). Thus, fisheries which are well stratified on broader shelves may overlap on these narrow ones. It is hence possible to consider the fishery targeting $C$. conger as not associated with deep-sea ecosystems on the northern part of the French shelf, and as a deep-water fishery on the southern part and on the Cantabrian shelf. Therefore, it is necessary to determine whether this fishery affects deep-water ecosystems and to study the performance of such shelf and slope fisheries on narrow shelves where target species may overlap. The fishery targeting $C$. conger on the French shelf is complementary to that targeting Molva spp. It uses very similar gear and has Molva spp. as the main accompanying species. Moreover, the 2 fisheries, together with the one targeting deep-sea sharks, have identical seasonality, with a marked decrease in effort during the summer. This decline is due to the fact that the fleet exploiting these resources focuses almost exclusively on $M$. merluccius during the summer because of its very high yields.

The gear used by fisheries targeting $C$. conger and P. blennoides in the Cantabrian Sea is the same (Punzón and Gancedo, 1998) and both fisheries take place during the same season. The seasonality of this gear is marked by a feature which is typical of artisanal fisheries, with a succession of target species during the year. Thus, this fishery occurs between the handline fishery targeting Scomber scombrus (Punzón et al., 2004) and the longline one targeting M. merluccius (Velasco, 2007), which take place in winter and spring, respectively, and the line fishery targeting Thunnus alalunga, which takes place in summer (GonzálezGarcés, 1996).

In the Gulf of Cádiz the fishery targeting silver scabbardfish has only recently started (Gil, 2006), and this species is the main accompanying species of the fishery targeting $P$. bogaraveo. Silver scabbardfish and blackspot seabream fishing tactics occur simulta- 
neously and the sharp decrease occurring in February and March is due to effort-regulating measures, which ban fishing activity between 15 January and 31 March.

The fishing patterns described here cannot be explained by the geographical distribution of the targeted species. All of them are distributed in all the areas, and the absence of species in landings of a specific area is due to fishing behaviour more than to species distribution. However, there are differences in bathymetry and ecology of the species which allow them to be divided into 3 groups of target species:

- Shelf species: $C$. conger dwells throughout the bathymetric range of the shelf (Alagador and Costa, 2003); P. blennoides and Molva spp. are outer shelf and shelf-break species (Sánchez and Serrano, 2003); within Molva species, M. macropthalma is a species with a shallower affinity (30-750 $\mathrm{m}$ ) than $M$. dypterigia and M. molva (both 100-1000 m).

- Bathyal species: the main commercial Macrouridae is the roundnose grenadier (Coryphaenoides rupestris), its depth range being 750 and $1200 \mathrm{~m}$ (Mauchline and Gordon, 1984). Alagador and Costa (2003) described a deep-water elasmobranch abundance increase below $700 \mathrm{~m}$.

- Species typical of particular topographic features such as slopes, seamounts, capes and banks: Beryx spp., Pagellus bogaraveo, and Hoplostethus spp., or the bathypelagic Trichiuridae and Alepocephalidae.

Phycis blennoides is one of the most abundant species at depths at which deep water fisheries work (the outer shelf and shelf break). For this reason, it is the only species which is exploited by both trawl and longline. Also, apart from being the target species of longline fisheries, it is one of the main accompanying species of trawling fisheries targeting M. merluccius in zones VIIIabd and VII, and longline fisheries targeting deep-sea sharks. The handline fishing tactics identified in the Gulf of Cádiz corresponded to those targeting $P$. bogaraveo and Trichiuridae, which were located around the volcanic seamounts which are common in the area. The fishery targeting Alepocephalus was conducted in the vicinity of large banks (Hatton, Rockall, Porcupine), where bathypelagic fauna is enhanced by topographic effects.

The identification of Spanish fishing activities from landings and using a multivariate methodology will be very useful for management tasks and for monitoring fishing impacts on deep sea habitats. Shifts in fishing behaviour can be easily detected using the methodology provided in this paper. It makes it possible to identify changes in the fishing tactics over time (disappearance of fishing tactics and the creation of new ones), and allows the trips to be classified annually using medoids of each cluster so that each one can be monitored individually. The combined use of landings information by fishing tactics with VMS data will provide accurate quantitative measures of effort and indices of relative abundance of species from areas where information is scarce or no research surveys have been conducted.

\section{ACKNOWLEDGEMENTS}

The authors would like to thank all IEO technicians involved in the sampling and data storage, and the "Ministerio de Medio Ambiente y Medio Rural y Marino" (MARM) for providing the logbook datasets.

\section{REFERENCES}

Alagador, D.A. and P.M. Costa. - 2003. Distribution patterns of deep-sea benthopelagic fish off the Algarve coast (Portugal). Bol. Inst. Esp. Oceanogr., 19 (1-4): 407-417.

Campos, A., P. Fonseca, T. Fonseca and J. Parente. - 2007. Definition of fleet components in the Portuguese bottom trawl fishery. Fish. Res., 83: 185-191.

Castro, J., A. Punzón, G.J. Pierce, M. Marín and E. Abad. - 2010. Identification of métiers of the Northern Spanish coastal bottom pair trawl fleet by using the partitioning method CLARA. Fish. Res., 102: 184-190.

Chessel, D., A.B. Dufour, S. Dray, with contributions from Lobry, J.R., S. Ollier, S. Pavoine, and J. Thioulouse. - 2005. ade4: Analysis of Environmental Data: Exploratory and Euclidean methods in Environmental sciences. R package version 1.4-0. http://pbil.univ-lyon1.fr/ADE-4.

Clark, M. - 2001. Are deepwater fisheries sustainable? The example of orange roughy (Hoplostethus atlanticus) in New Zealand. Fish. Res., 51: 123-13.

D’Onghia, G., C.Y. Politou, A. Bozzano, D. Lloris, G. Rotllant, L. Sion, and F. Mastrototaro. - 2004. Deep-water fish assemblages in the Mediterranean Sea. Sci. Mar., 68(Suppl. 3): 87-99.

Devine, J. A., K. D. Baker and R.L. Haedrich. - 2006. Fisheries: Deep-sea fishes qualify as endangered. Nature, 439: 29-29.

Durán, P. and E. Román. - 2001. The Spanish Multi-species Deepsea Fishery on Hatton Bank (North East Atlantic): 1996-2000. NAFO SCR Doc. 01/120.

Froese, R. and D. Pauly (eds). - 2007. FishBase. World Wide Web electronic publication. www.fishbase.org, version (10/2007).

Gil, J. - 2006. Biología y pesca del voraz, Pagellus bogaraveo (Brünnich, 1768), en el Estrecho de Gibraltar. PhD thesis, Univ. Cádiz.

González-Garcés, A. - 1996. Contribución al conocimiento de la dinámica de la población del atún blanco Thunnus alalunga Bonnaterre, 1788 del Atlántico norte. $\mathrm{PhD}$ thesis, Universidad Complutense de Madrid, $208 \mathrm{pp}$.

Gordon, A.D. - 1999. Classification, ${ }^{\text {nd }}$. ed. Chapman and Hall, London.

Gordon, J.D., O.A. Bergstad, I. Fegueiredo and G. Menezes. - 2003 Deep-water Fisheries of the Northeast Atlantic: I. Description and Current Trends. J. Northwest Atl. Fish. Sci., 31: 137-150.

Haedrich, R.L., N.R. Merrett and N.R. O'Dea. - 2001 Can ecological knowledge catch up with deep-water fishing? A North Atlantic perspective. Fish. Res., 51; 113-122.

Hair, J.F., R.E. Anderson, R.L. Tatham and W.C. Black. - 1999. Multivariate Data Analysis. Fifth edition. Prentice Hall International Inc.

Herráiz, I.G., M.A. Torres, A.C. Fariña, J. Freire and J.R. Cancelo. -2009 . The NAO index and the long-term variability of $\mathrm{Ne}$ phrops norvegicus population and fishery off West of Ireland. Fish. Res., 98(1-3): 1-7.

Hilborn, R. and J.C. Walters. - 1992. Quantitative fisheries Stock assessment. Chapman and Hall, New York.

Hill, M.O. and H.G. Gauch. - 1980. Detrended correspondence analysis: an improved ordination technique. Vegetatio, 42: $47-58$.

ICES. - 2007. Report of the Planning Group on Commercial Catch, Discards and Biological Sampling (PGCCDBS). ICES CM 2007/ACFM:09.

ICES. - 2008. Report of the Working Group on the biology and Assessment of Deep Sea Fisheries Resources (WGDEEP). ICES CM 2008/ACOM:14.

ICES. - 2010. Report of the Working Group on the biology and Assessment of Deep-Sea Fisheries Resources (WGDEEP). ICES CM 2010/ACOM:17.

Iglesias, S. and J. Paz. - 1995 Spanish north Atlantic deep-water 
fisheries. In: Hooper, A.G. (Ed.) Deep-water fisheries of the north Atlantic oceanic slope, pp. 287-295. Klower Academic Publishers, Dordrecht, the Netherlands.

Jiménez, M.P., I. Sobrino and F. Ramos. - 2004. Objective methods for defining mixed-species trawl fisheries in Spanish waters of the Gulf of Cádiz. Fish. Res., 67: 195- 206.

Kaufman, L. and P.J. Rousseeuw. - 1986. Clustering large sets (with discussion). In: E.S. Gelsema and L.N. Kanal (eds.), Pattern Recognition in Practice II, pp. 405-416. Elsevier/North Holland, Amsterdam.

Koslow, J.A., G.W. Boehlert, J.D. Gordon, R.L. Haedrich, P. Lorance and N. Parin. - 2000. Continental slope and deep-sea fisheries: implications for a fragile ecosystem. ICES J. Mar. Sci., 57: 548-557.

Large, P. A., C. Hammer, O.A. Bergstad, J.D.M. Gordon and P. Lorance. - 2003. Deep-water Fisheries of the Northeast Atlantic: II. Assessment and Management Approaches. J. Northwest Atl. Fish. Sci., 31: 151-163.

Lauzanne, L. - 1975. Régimes alimentaires d'Hydrocyon forskalii (Pisces, Characidae) dans le Lac Tchad et ses tributaires. Cah. ORSTOM Hydrobiol., 9(2): 105-121.

Lorance, P. and H. Dupouy. - 2001. CPUE abundance indices of the main target species of the French deep-water fishery in ICES Sub-areas V-VII. Fish. Res., 51: 137-149.

Maechler, M., P. Rousseeuw, A. Struyf and M. Hubert. - 2005. cluster: Cluster Analysis Basics and Extensions. R package version 1.10.2. http://cran.r-project.org/web/packages/cluster/

Mauchline, J. and J.D.M. Gordon. - 1984. Diets and bathymetric distributions of the macrourid fish of the Rockall Trough, Northeastern Atlantic Ocean. Mar. Biol., 81: 107-121.

Milligan, G.W. - 1980. An examination of the effect of six types of error perturbation on fifteen clustering algorithms. Psychometrica, 45: 325-342.

Morato, T., R. Watson, T.J. Pitcher and D. Pauly. - 2006. Fishing down the deep. Fish Fish., 7: 24-34.

Oksanen, J., R. Kindt and R.B. O'Hara. - 2006. vegan: Community Ecology. R package version 1.6-10. http://cc.oulu.fi/ jarioksa/.

Piñeiro, C.G., M. Casas and R. Bañón. - 2001. The deep-water fisheries exploited by Spanish fleets in the Northeast Atlantic: a review of the current status. Fish. Res., 51: 311-320.

Punzón, A. and R.M. Gancedo. - 1998. Specific characterisation and identification of the fishing gears in use in the Cantabrian sea (NE Atlantic, Northern Spain). ICES CM 1998/U:7.

Punzón, A., C. Hernández, E. Abad, J. Castro, N. Pérez and V. Trujillo. - 2010 Spanish otter trawl fisheries in the Cantabrian Sea. ICES. J. Mar. Sci., 67: 1-13.

Punzón, A., B. Villamor and I. Preciado. - 2004. Analysis of the handline fishery targeting mackerel (Scomber scombrus, L.) in the North of Spain (ICES Division VIIIbc). Fish. Res., 69: 189-204.

R Development Core Team. - 2005. R: A language and environment for statistical computing. R Foundation for Statistical Computing, Vienna, Austria. ISBN 3-900051-07-0, URL http:// www.R-project.org.

Rosecchi, E. and Y. Nouaze. - 1985. Comparaison de cinq indices alimentaires utilisés dans l'analyse des contenus stomacaux. Rev. Trav. Inst. Pech. Marit., 49(3-4): 111-123.

Rousseeuw, P.J. - 1987. Silhouettes: a graphical aid ot the interpretation and validation of cluster analysis. J. Comput. Appl. Math., 20: 53-65.

Sánchez, F. and A. Serrano. - 2003. Variability of groundfish communities of the Cantabrian Sea during the 1990s. ICES Mar. Sci. Symp., 219: 249-260.

Struyf, A., H. Mia and P.J. Rousseeuw. - 1996. Clustering in an object-oriented environment. J. Stat. Softw., 1(4): 1-30.

Velasco, F. - 2007. Alimentación de la merluza europea (Merluccius merluccius L.) en el mar Cantábrico. $\mathrm{PhD}$ thesis, Univ. Complutense Madrid.

Vinther, M., S. A. Reeves and K. R. Patterson, - 2004. From singlespecies advice to mixed-species management: taking the next step. ICES J. Mar. Sci., 61: 1398-1409.

Scient. ed.: F. Maynou.

Received May 12, 2010. Accepted January 5, 2011.

Published online April 11, 2011 